DOI: $10.20472 / E F C .2018 .009 .015$

\author{
SHAGUFTA SHABBAR \\ Institute of Business Administration, Pakistan
}

QAZI MASOOD AHMED

IBA, Pakistan

FAROOQ PASHA

State Bank of Pakistan, Pakistan

\title{
A JUXTAPOSITION OF TAX EXPENDITURES AND DIRECT EXPENDITURES: CASE STUDY OF THE MANUFACTURING SECTOR OF PAKISTAN
}

\begin{abstract}
:
Augmentation of investment is a primary goal for any government. To attain that objective it can resort to either tax or direct expenditures. In order to analyze which is a more efficient method in the case of Pakistan, the current study uses data from the country's Manufacturing Sector. The time series data set since 1972 to 2013 is used. Bounds testing approach to cointegration used in the structure of Autoregressive Distributed Lag is employed for understanding the behavior of the different variables, applying Neo-Classical Investment theory. The results show the importance of tax expenditure policy, in the short run, through the cost of capital, as a determinant to boost private investment in the economy, under circumstances of low inflation. On the other hand, in high inflation periods, the direct expenditure is found to be more potent. The empirical evidence shows a strong role of direct expenditure in influencing both the short-run and the long-run behavior of investment in the economy.
\end{abstract}

\section{Keywords:}

Investment, cost of capital, tax expenditure, ARDL, manufacturing sector, Pakistan.

JEL Classification: H25, H54, E22 


\section{Introduction}

In order to entice investors, the government of Pakistan, has offered different investment incentives in the form of tax and direct expenditures. The taxation policy is perceived to be a significantly leading factor in ascertaining the level of investment through the cost of capital. The cost of capital hinges on the rate of return, the price of the capital good and the corporate tax rate. The current paper uses the Jorgenson's $(1963,1967)$ Neo-Classical Investment model to evaluate the importance of cost of capital in determining the level of investment. Direct expenditures, on the other hand, seem to be generating sensitivity in the level of investment, both in the short and long run, in the case of Pakistan. The current study; therefore, tries to analyze which expenditure demonstrates more potency, in the case of Pakistan, and thus suggest the increase in the usage of the superior expenditure to attain the goal of higher growth rates through escalation of investment level.

To boost investment, tax expenditures are used which decrease the tax liabilities of the investors. While Surrey $(1973,1985)$ established tax expenditure as a separate branch of Public Finance, the superiority of tax expenditures over direct expenditures was established in 1980 by Martin Feldstein in his paper. Tax expenditures are provisions by the government that allow exemptions, credit, deferrals, deductions and preferential rates. This is given to a specific group or for selected activities in the targeted industry. There is a fervent belief in Pakistan that one of the cardinal causes of low tax to GDP ratio in the country, is a huge amount of tax expenditure. According to the Pakistan Economic Survey 2014-15, it was Rs. 665.0 billion. This is thus 2.4 percent of the total GDP of Pakistan. Pasha and Ghaus-Pasha (2015), present an estimate of the tax expenditure which they claim to be nearly three times higher than the official reported figure in the FY 2011. The tax expenditure, currently under study, is accelerated depreciation allowance, and this too is not included in the PES estimates.

The focus of the current study is on the manufacturing sector. It is termed as the "most dynamic component of the industrial sector." The importance of the sector propels the government to boost it by creating an environment for attracting investment in it. The ability of the two expenditures to amplify corporate sector investment, in Pakistan, is tested using time series data from 1972 to 2013, of the Manufacturing Sector, employing Autoregressive Distributed Lag (ARDL) approach as proposed by Pesaran and Shin (1995) and Pesaran, Shin, and Smith (2001). Next, a comparison is made between the two expenditures to analyze the most effective tool for the government. The main objectives of the current study are to explore the main determinants of private investment and find which expenditure demonstrates more potency.

\section{Literature review}

The neoclassical theory is based on the premise that whenever it is profitable, the investors borrow so that they can invest in capital. It analyzes how the investment is reliant on the marginal productivity of capital, interest rate and economic policies related to taxes. Economic policies, such as corporate income tax and investment tax credit, vary the motivations to invest and thus bring about a shift in the investment function, causing a rise or decrease in investment. When Johansson, Heady, Arnold, Brys, and Vartia (2008) analyzed the impact of taxes taking it as an increase in the cost of capital, the result was in favor of the economists' notion. Taxes are a source of excess burden, and causes input and employment effects (Musgrave \& Musgrave, 1989). Investment tax credit decreases the tax entirely and is advantageous for short term assets. In the case for Pakistan it is zero. The investment behavior stimulus given through the tax policy of the government is based on the notion that investors find investment appealing when it costs them less (Hall \& Jorgenson, 1967). Both accelerated depreciation allowance and investment tax credit are tools for providing incentives to the investors. Hall and Jorgenson (1967), measure the cost of capital, comprising of the tax treatment and the interest rate; and then determine its effect on investment using the flexible accelerator theory of investment. They deduced that the level of investment is highly dependent on the tax policy working through the cost of capital, along with the timing and composition of investment expenditures.

The study of tax expenditures as a divergent in public finance was delineated by (Surrey, 1970). Tax expenditures are tools for attaining governmental objectives of both fiscal and social (A. M. Ahmed \& Ather, 2014). Tax expenditure is considered a kind of respite for the investor which is not a part of the actual tax structure but is included due to some motive. Particularly considering the accelerated depreciation allowance, 
Zee, Stotsky, and Ley (2002), avow that this has the least defects and most benefits. Musgrave and Musgrave (1989), consider the tax expenditures equal to the dereliction to collect taxes. It is problematic to evaluate tax expenditures and there are few beneficiaries of the exemptions (A. M. Ahmed \& Ather, 2014). They enunciate that Pakistan's weak buoyancy of tax structure is associated with the large exemptions given to certain segments in the economy. The tax expenditure currently under study is not even mentioned in the Pakistan Economic Survey. Tax expenditure is considered to have a prominent deficiency in the shape of its ability to allow tax evasion and tax avoidance (Q. M. Ahmed, 2001). The measurement of tax expenditure entails a thorough understanding of the essential tax structure without which the expenditure may be over or under stated. (Altshuler \& Dietz, 2008; Surrey, 1970; Thuronyi, 1988) asserted that tax expenditures breed inequity and cause distortion in the marketplace. Fuest and Riedel (2009) and Kahn (1979) labelled them as hidden expenditures as they are not visible in the tax system and thus escape inspection unlike their counterpart.

In 1970, Surrey contended that regarding ways to achieve social goals the tax expenditures scored less than direct expenditures. However, Q. M. Ahmed (2001) argued and presented evidence showing that tax expenditures showed better efficacy. Similarly, Feldstein (1982, as cited in Chirinko, 1993) too advocated that under specific circumstances the tax expenditure surpassed the direct expenditure.

It is declared by Ahmad and Qayyum (2008) that government expenditures are an important determinant of investment and that the upsurge of direct expenditures may bring improvement in investment. However; there has been an ages old debate between the Classicals and the Keynesians about the effect of direct expenditure. The latter arguing that there is a crowding in effect for investment due to the expenditure; however, the former have propounded the impact to be a crowding out effect. Akkina and Celebi (2002) concluded from their research that there was a crowding out effect in the country of their study i.e. Turkey. Hussain, Muhammad, Akram, and Lal (2009) conclude that since Pakistan being a developing country, the Classical's theory is not applicable here. Hussain et al. (2009), using cointegration technique, restate that direct expenditures, used for development of infrastructure, tend to crowd-in private investment.

A vast body of research has been conducted over the years to try to understand the various dimensions of investment. Flexible acceleration principle assumed an optimal relationship between the capital stock and output. The neo-classical school of thought expounded by Jorgenson stated that investment theory was based on the "optimal capital accumulation." The investment demand function is derived using the optimal capital stock. The seminal paper by Jorgenson (1967) stressed on the importance of the user cost of capital as being an important determinant of the capital stock. He further described the cost of capital as being made up of the interest rate, depreciation rate, corporate tax rate, and the depreciation for tax purposes. To consider the investing firm's behavior, the neo-classical model has been used by multitude of economists (Jorgenson and Siebert, 1968; Auberach, 1983; Chirinko 1993; Ahmed 2001). Jorgenson (1971) juxtaposed surrogate stipulations of investment models, which included demand for capital determinants, investment gestation lags relevance and replacement investment modelling. The assimilation of the tax structure in the cost of capital has facilitated providing a link between the factors determining investment and the economic policy (Bischoff, Bosworth, \& Hall, 1971).

Hyder and Ahmed (2003) assert that interest rate act as a prominent determinant of investment in the manufacturing sector of Pakistan. Kemal (2006), analyzed the issues in the manufacturing sector and deduced that investment is determined by cost of capital and due to the high degree of taxation in Pakistan, among other factors, the level of investment is low. Stability of government, exchange rate policy, rate of interest and the tax structure are the determinants, identified by Amjad (2008) which serve to boost private investment in Pakistan.

However; both internal and external shocks impact the level of investment in the manufacturing sector, including but not limited to sanctions post the nuclear blast, military coup, event of 9-11, exchange rates and so on (Hyder and Ahmed, 2003; Ahmad and Qayyum (2008); Zaidi, 2015). Disturbances could include a sudden surge in foreign direct investment or switching of managed exchange rate to a floating exchange rate. Since there is an inability to quantify such uncertainties, the usage of crude proxies, in order to capture these uncertainties, is a common practice Ahmad and Qayyum (2008). Thus the current study tries to account for these factors by creating dummies and uses them in the estimation. 


\section{Theoretical framework \& Methodology}

To compute investment is a daunting task and to ascertain its main determinants is labyrinthine (Amjad, 2008). The "neo-classical theory of investment" (Hall \& Jorgenson, 1967) is the basis for the function of investment used for this paper. The theory necessitate for the specification of equations for the net investment and for the cost of capital. The investment equation relies on the stock adjustment model. Profit $(\pi)$ maximization is the main objective of the producer. In order to produce the profit maximization level of output the producer makes adjustments in the stock. The stock adjustment model assumes that the producer makes adjustments and chooses that level of stock where marginal revenue of the additional machine will be equal to the marginal cost of hiring that machine. The cost is a function of the capital stock. The cost of the capital is estimated through neo-classical investment model as expounded by Jorgenson (1967). It is made up of the interest rate, depreciation, tax rate and the price of capital. Hall and Jorgenson (1967) deduce the cost of capital as

$$
\mathrm{c}=\mathrm{q}(\mathrm{r}+\delta) \frac{(1-\mathrm{k})(1-\mathrm{uz})}{(1-\mathrm{u})}
$$

The cost of capital is the expected cost incurred by the firm by using a unit of the capital. The interest rate, $r$, is the opportunity cost of using money. The depreciation cost of capital usage is the loss in value as the capital wears out over time. Investment tax credit is denoted by $\mathrm{k}$. The tax rate, $\mathrm{u}$, is the corporate tax rate determined by the government. The depreciation deduction present value, $z$, is calculated as per the income tax ordinance of Pakistan legal provision. To calculate $z$ the procedure indicated by Ahmed (2001) is utilized. The depreciation deduction, for the method of straight line depreciation, is constant over the period $\mathrm{T}$. Where $T$ is the life time of capital good. Assuming that there is no salvage value of the asset, and following Hall and Jorgenson (1967), "the present value of the depreciation deduction is"

$$
z=\frac{1}{r \tau}\left(1-e^{-r \tau}\right)
$$

"The present value of the depreciation of a unit of investment in Pakistan is computed on the basis of $10 \%$ of the value of machinery and plant as normal depreciation, and $25 \%$ as initial allowance. This implies that $35 \%$ of the total value of machinery will be charged in the first year and the remaining $65 \%$ in 6.5 years (straightline method)" (Ahmed, 2001). This means that in 7.5 years the total value of plant and machinery will be charged. So now the cost of capital under zero capital gain assumption is

$$
\mathrm{c}=\mathrm{q}(\mathrm{r}+\delta) \frac{(1-k)}{(1-u)}\left\{1-\mathrm{u}\left[0.25+\frac{1}{r \tau}\left(1-e^{-r \tau}\right)\right]\right\}
$$

Therefore, $\mathrm{c}$ is the yearly cost of using one unit of capital good. It comprises of the interest rate, depreciation rate, investment tax credit, tax rate, depreciation allowances and the life time of capital goods.

A firm wants to maximize its profit. In order to increase profit it must increase its output which can be done by increasing capital. Investment is made by the firms in order to increase its capital stock and reach the desired capital stock. The desired capital stock is the level of capital stock at which the tax adjusted cost of capital is equal to the "expected future marginal product of capital." Net investment is then the change in the capital stock. According to the flexible accelerator model, the rate of a firm's investment depends on the gap between the current capital stock of the firm and its desired level of capital stock. More the gap, more rapid is the rate. Following Jorgenson (1967), the production function is assumed to be Cobb-Douglas and strictly convex

$$
K^{*}=\alpha \frac{p Q}{c}
$$

Here $\mathrm{K}^{*}$ is the desired level of capital stock, and $\alpha$ the elasticity of output with respect to capital. The desired level of capital stock is equal to the gross revenue (pQ) times the elasticity with respect to capital, $\alpha$ (assumed to be constant); divided by the cost of capital, c. Hence, the desired capital stock depends on the value of output and the cost of capital. The net investment is taken as the change in the capital stock

$$
N I=\Delta K
$$


In order to obtain a regression function $\varepsilon_{t}$ an independent and identically distributed random error term is added, $\varepsilon_{t} \sim i i d\left(0, \sigma^{2}\right)$. And using the marginal productivity of capital condition the equation, with $\alpha$ which is the elasticity of output with respect to capital, becomes

$$
N I_{s}=\alpha \lambda_{0} \Delta K_{s}^{*}+\alpha \lambda_{1} \Delta K_{s-1}^{*}-\omega N I_{s-1}+\varepsilon_{S}
$$

Replacing $\mathrm{K}^{*}$, the function becomes

$$
N I_{s}=\alpha \lambda_{0} \Delta \frac{p_{s} Q_{s}}{c_{s}}+\alpha \lambda_{1} \Delta \frac{p_{s-1} Q_{s-1}}{c_{s-1}}-\omega N I_{s-1}+\varepsilon_{s}
$$

Here $\alpha, \lambda$ and $\omega$ are unknown parameters that need to be estimated. The net investment equation is used here to test the impacts of the type of the two expenditure policies of the government. It is adapted to the specification of the Pakistan's economy keeping in mind that different variables may work differently in different countries. Output and the cost of capital determine the desired capital stock, and via this desired capital stock the investment function is effected by a change in the tax policy of the government. This model makes the assumption that a change in the level of output is deliberated as an essential barometer to determine the resolve of the investors to invest. The tax expenditure policy of the government influences the investment through the cost of capital. While the impact, on net private investment, of the direct expenditure policy of the government is captured through the governmental investments i.e. PSDP. The reason to include it is this that if the government does not invest in enabling infrastructures than investment is shunned. This is of high relevance in Pakistan which is still a developing country. Next, dummies are included in order to capture other factors impacting investment i.e. political situation of the country, exchange rate regime and level of foreign direct investment.

$$
(\text { investment })_{t}=\alpha_{0}+\beta_{1}(\text { output })_{t}+\beta_{2}(P S D P)_{t}+\beta_{3}(\text { cost of capital })_{t}+\text { dummies }+\varepsilon_{t}
$$

The accelerator theory model takes into account the past variations in output while ascertaining investment. However, Clark (1979) and others recently have used the level of output in order to estimate investment. The problem of simultaneity between investment and output does not exists because nonresidential investment, which is being estimated, is only part of the total investment (Clark, 1979). Clark further asserted that as per his Sims test the problem of simultaneity was not grave.

\section{Data requirements \& Estimation Technique}

For the current study, Pakistan's large scale manufacturing sector annual data is used for the period 1972 to 2013. The data are taken from the Handbook of Statistics on Pakistan Economy (State Bank of Pakistan), FBR, and various issues of Economic Survey of Pakistan. The variables used are large-scale manufacturing output deflated using the GDP deflator; gross fixed capital formation as investment in plant and machinery; user cost of capital capturing the tax expenditure; the public sector development plan, as a proxy for direct expenditure, deflated using the GDP deflator; a dummy, to capture the prevailing political situation in the country; a dummy, to account for the fixed, managed and floating exchange rate periods; and a dummy for foreign direct investment, to account for greater and less than 1 billion Rs FDI. The justification for using these dummies is that firstly, A. R. Kemal (2006), avers that foreign exchange rate in Pakistan is a determinant of investment. The lower value of dollar helps intensification of investment. Also, Shah, Ahmed, and Siddiqui (2003), enunciate that FDI flows are now being directed towards developing countries due to their inviting policies; however, Pakistan seemed to be lacking that luster. But now the recent years have shown an improvement in FDI flows.

There are three types of assets; machinery and equipment, buildings, and inventories. For the current study only investment in plant and machinery is taken into consideration. For calculation of investment in plant and machinery, the data on gross fixed capital formation is used. However, gross fixed capital formation comprises of several expenditures such as buildings, furniture and fixtures, and plant and machinery etc. The focus of this paper is solely investment on plant and machinery. But due to the lack of data availability, this proxy was used on the justification that "the share of plant and machinery was around $70 \%$ " as assumed by Ahmed (2001). Following Ahmed, "net investment is calculated by subtracting 10\% value of depreciation from the corresponding gross fixed capital formation." The figures obtained are also deflated using the machinery 
import value index. It is assumed that all plant and machinery is imported. The variables are deflated so as to eliminate the effect of shared price trends. To avoid the heteroskedasticity issue and linearize the variables, the natural log of the variables; investment, output and PSDP, is taken. Since user cost of capital is a rate therefore the natural log of it is not taken. All these variables are in million rupees.

The cost of capital variable has been constructed using the equation discussed in the section of theoretical framework. The interest rate is the weighted average rates of return on advances less the inflation. The depreciation taken in the current study, as mentioned in the third schedule of the Income Tax Ordinance, for plant and machinery the normal depreciation is $10 \%$; initial depreciation allowance is $25 \%$. Therefore, this means that in the first year " $35 \%$ of the total value of machinery will be charged." The lifetime is the time the asset is estimated to be of use for the investor. Taking 7.5 years as the total life time of the asset, the rest of the depreciation that is $65 \%$ is apportioned over the next 6.5 years using straight-line method. Lastly, the salvage value is the predicted price at which the asset will be disposed of and in the current study it is taken as zero. Since the data for depreciation of plant and machinery is not available, it was taken as the difference of gross national product and net national product divided by gross national product. The corporate income tax rate is levied by the government as three different rates to the three different companies i.e. banking, private and public companies. The focus of the present study is private companies only. Following Ahmed (2001), the cost of capital is calculated in accordance with the legal provisions which grant exemption from the income tax to the capital gain and "the face value of the bonus share" but not to the interest payments. Another assumption carried here is that the loan is the only source through which the investment has been financed. The "carry forward tax loss provision" is not counted in the calculation of the cost of capital due to the impossibility of getting data from any reliable source.

The table below shows the present value of the depreciation allowance available to the investors, for some selected years. This depreciation allowance is deducted from the total cost in order to get the cost of capital incurred by the investors. It is listed along with the nominal interest rate. In periods of high inflation, the real interest becomes very low. In eight years out of the total period of study, the inflation was so high that the real interest rate was negative. This affects the present value of accelerated depreciation calculated needed for tax purposes. The interest rate fluctuations brings variations in the depreciation allowance.

Table 1: Present Value of Accelerated Depreciation Allowance for the period of study i.e. 1972-2013 (selected years)

\begin{tabular}{|l|l|l|}
\hline Year & $\begin{array}{l}\text { Nominal } \\
\text { Interest Rate }\end{array}$ & $\begin{array}{l}\text { Present Value of } \\
\text { Accelerated } \\
\text { Depreciation } \\
\text { Allowance }\end{array}$ \\
\hline 1972 & 0.0845 & 0.6135 \\
\hline 1976 & 0.0986 & 0.6133 \\
\hline 1979 & 0.1153 & 0.6552 \\
\hline 1982 & 0.1182 & 0.6244 \\
\hline 1986 & 0.128 & 0.5132 \\
\hline 1989 & 0.1362 & 0.4810 \\
\hline 1992 & 0.1411 & 0.5462 \\
\hline 1996 & 0.1519 & 0.5241 \\
\hline 1999 & 0.1563 & 0.3917 \\
\hline 2006 & 0.0911 & 0.4184 \\
\hline 2002 & 0.1368 & 0.3390 \\
\hline 2009 & 0.1404 & 0.4254 \\
\hline 2012 & 0.1243 & 0.4059 \\
\hline 2013 & 0.1153 & 0.3752 \\
\hline
\end{tabular}




\section{Source: Author's Estimation}

The tabulated values below are the calculated values of the cost of capital, using the formula discussed earlier, for the period of study i.e. 1972-2013. The depreciation allowance is deducted from the total unit cost of capital, to get this cost of capital.

\section{Table 2: Calculated values of Cost of Capital}

\begin{tabular}{|c|c|}
\hline Year & Cost of Capital \\
\hline 1972 & 0.092791304 \\
\hline 1973 & -0.003533937 \\
\hline 1974 & 0.279039186 \\
\hline 1975 & 0.006924751 \\
\hline 1976 & 0.085336969 \\
\hline 1977 & 0.058083942 \\
\hline 1978 & 0.100645379 \\
\hline 1979 & 0.055706417 \\
\hline 1980 & 0.036842405 \\
\hline 1981 & 0.01630498 \\
\hline 1982 & 0.077462621 \\
\hline 1983 & 0.117939212 \\
\hline 1984 & 0.099258863 \\
\hline 1985 & 0.106524718 \\
\hline 1986 & 0.185080471 \\
\hline 1987 & 0.130223037 \\
\hline 1988 & 0.108655754 \\
\hline 1989 & 0.110175903 \\
\hline 1990 & 0.093262034 \\
\hline 1991 & 0.04908198 \\
\hline 1992 & 0.105214845 \\
\hline 1993 & 0.111876338 \\
\hline 1994 & 0.080673101 \\
\hline 1995 & 0.080348601 \\
\hline 1996 & 0.090546519 \\
\hline 1997 & 0.072590277 \\
\hline 1998 & 0.177261389 \\
\hline 1999 & 0.201560316 \\
\hline 2000 & 0.185102913 \\
\hline 2001 & 0.228565376 \\
\hline 2002 & 0.177373073 \\
\hline 2003 & 0.168786553 \\
\hline 2004 & 0.052871302 \\
\hline 2005 & 0.056764661 \\
\hline
\end{tabular}




\begin{tabular}{|l|c|}
\hline 2006 & 0.082186527 \\
\hline 2007 & 0.105457039 \\
\hline 2008 & -0.013408724 \\
\hline 2009 & 0.06685736 \\
\hline 2010 & 0.061618027 \\
\hline 2011 & 0.064272432 \\
\hline 2012 & 0.072249651 \\
\hline 2013 & 0.101296916 \\
\hline
\end{tabular}

Source: Author's Estimation

The regression uses time series data. This time series data has some challenges and using simple OLS may give spurious results. If the series is non-stationary than it might give the problem of autocorrelation. It is imperative to check the stationarity of time series data. If it is not stationary then it will not be possible to generalize the results to other time periods. Engle and Granger, (1987) state that when each variable (time series) is difference stationary, it will have cointegration of order $(1,1)$ (have a long run relationship), when there is no necessity to difference the linear combination of the series. This means that though there might be permanent changes in discrete variables, the variables are tied to each other due to a long run equilibrium relationship. Thus cointegration suggests that there is equilibrium though there is a finite variance disturbance which is stationary. Regression may give spurious results if cointegration is ignored and non-stationary or trend variables are regressed on each other.

Upon testing the order of integration using the Augmented Dickey-Fuller test, Phillips-Perron, and the NgPerron test on the log of the variables, it is confirmed that except one of the time series all others contains a unit root. Since it is found that except one which is I (0), all other variables are I (1); thus models such as Engle Granger (1987), Johansen (1988) and Stock and Watson (1993) cannot be used. Therefore the bounds testing procedure will be used to determine the relationship between the variables. Another issue with time series is that the sample size should be sufficiently large; however, in bounds testing, the estimators, of both long run as well as short run, are found to be consistent even in small sample size. Since the current study has a sample size of 41 observations, this approach is found to be quite appropriate.

Having known that there is in fact an existence of a relationship the autoregressive distributed lag model, suggested by Pesaran and Shin in 1999, can be applied to estimate the ECM. For a useable deduction from the ARDL approach it is necessary to select a suitable order of the model. 108 different ARDL models are estimated in this analyzes. Pesaran and Shin (1998), find that Schwarz Criterion (SC) is a more consistent model when compared to Akaike Information Criterion (AIC). The smallest probable lag length is chosen by SC while AIC tends to choose the largest applicable length. (Li \& Lin, 2015;Shahbaz, Ahmad, \& Chaudhary, 2008; Waliullah, Kakar, Kakar, \& Khan, 2010), state that to get the optimum lag length, the ARDL model evaluates $(k+1)^{p}$ number of regressions. Here $k$ is the highest number of lags that can be used whereas $p$ denotes the number of variables present in the equation. Once the order of the ARDL model is determined the long run parameters and their standard errors can be determined.

The model chosen for this study fulfills all the assumptions of the ARDL model as specified by Pesaran and Shin (1998). Namely, error term is independent and identically distributed, the regressors are not cointegrated, and the model is stable. The presence of a long run relationship is scrutinized by the ARDL approach to cointegration using the unrestricted error correction model which is as follows:

$\Delta \ln (\text { investment })_{t}$

$$
\begin{aligned}
& =\alpha_{0}+\sum_{i=1}^{n} \gamma_{i} \Delta \ln (\text { invstment })_{t-i}+\sum_{i-0}^{n} \delta_{i} \Delta \ln (\text { output })_{t-i}+\sum_{i-0}^{n} \varphi_{i} \Delta \ln (P S D P)_{t-i} \\
& +\sum_{i=0}^{n} \omega_{i} \Delta(\text { cost of capital })_{t-i}+\beta_{1} \ln (\text { investment })_{t-1}+\beta_{2} \ln (\text { output })_{t-1}+\beta_{3} \ln (P S D P)_{t-1} \\
& +\beta_{4}(\text { cost of capital })_{t-1}+\zeta_{1} \text { Dummy }_{1}+\zeta_{2} \text { Dummy }_{2}+\zeta_{3} \text { Dummy }_{3}+\varepsilon_{i}
\end{aligned}
$$


The former part of the equation having coefficients $\gamma_{i}, \delta_{i}, \varphi_{i}$, and $\omega_{i}$ symbolizes the short run dynamics of the model. On the other hand the long run relationship is depicted by the latter part of the equation having coefficients $\beta_{1}, \beta_{2}, \beta_{3}$, and $\beta_{4}$. In this equation In is the natural logarithm and $\varepsilon_{i}$ is the random error term. $\alpha_{0}$ is the constant. Dummies are included to complete the information.

The Wald test (F-statistic) estimates the long run coefficients. The joint $F$ statistic forms the basis of the bounds test which has an asymptotic distribution and is nonstandard having no cointegration (no long run relationship) as its null hypothesis. Bounds test is run to see if the F-statistics is greater than the upper critical bound. The null hypothesis of no long run relationship is rejected and it is reasoned that cointegration exists amongst the variables. When the presence of long-run relationship is established (rejection of null hypothesis), the long-run model is estimated. ARDL regression is employed to obtain long run elasticities of the variables. Next, error correction model is estimated. The SC gives the optimal lag length of variables. The significance of the error correction term proofs the presence of causality in at least one direction. The negative value of the error term and its level of significance show the rate of convergence to the long-run equilibrium, after a shock in the short-run.

\section{Empirical Results}

The descriptive statistics show normal distribution of the variables. Upon analyzing it is observed that Manufacturing output and PSDP seem to be correlated. One way to resolve this issue is to drop any one of the variables; however this may cause specification bias. Upon testing the variance inflation factor, it is observed that the values are less than 10 and so the multicollinearity problem is not considered grave. Coefficient variance decomposition matrix is made to analyze the possibility of collinearity between the regressors.

The results of the unit root tests are presented in the table below. The first difference of the three variables i.e. Innil, Inoml and Inpsdp; investment, manufacturing output, and PSDP, reject the null hypothesis and it is concluded that the variables are stationary at first difference. While cost of capital is found to be stationary at level.

Table 3: Unit Root Estimation 1

\begin{tabular}{|c|c|c|c|c|c|c|c|c|}
\hline \multirow[t]{2}{*}{ Variables } & \multicolumn{2}{|c|}{ ADF Unit Root Test } & \multicolumn{2}{|c|}{ PP Unit Root Test } & \multicolumn{4}{|c|}{ Ng-Perron Unit Root Test } \\
\hline & T-statistic & Prob. value & T-statistic & Prob. value & $\mathrm{MZ} \mathrm{Z}_{\alpha}$ & $M Z_{t}$ & MSB & MPT \\
\hline uc & $-5.138^{*}(0)$ & 0.0008 & $-5.288^{*}(3)$ & 0.0005 & $-19.834^{* *}(0)$ & $-3.149^{* *}$ & $0.159^{* *}$ & $4.595^{\star *}$ \\
\hline InniL & $-2.943(0)$ & 0.1605 & $-3.174(1)$ & 0.1037 & $-9.647(0)$ & -2.168 & 0.225 & 9.565 \\
\hline Inoml & $-2.048(0)$ & 0.5586 & $-2.338(2)$ & 0.4050 & $-6.829(0)$ & -1.821 & 0.267 & 13.367 \\
\hline Inpsdp & $-1.376(0)$ & 0.5844 & $-1.376(0)$ & 0.5844 & $-1.869(0)$ & -0.658 & 0.352 & 9.736 \\
\hline dlnniL & $-6.364^{\star}(0)$ & 0.0000 & $-7.836^{\star}(10)$ & 0.0000 & $-16.14^{\star * \star}(0)$ & $-2.84^{* \star \star}$ & $0.176^{\star \star \star}$ & $5.65^{\star \star}$ \\
\hline dlnoml & $-2.187^{\star *}(1)$ & 0.0293 & $-3.804^{*}(3)$ & 0.0003 & $-19.831^{*}(0)$ & $-3.101^{*}$ & $0.156^{*}$ & $1.404^{*}$ \\
\hline dlnpsdp & $-7.574^{\star}(0)$ & 0.0000 & $-7.505^{\star}(2)$ & 0.0000 & $-19.255^{\star}(0)$ & $-3.103^{*}$ & $0.161^{*}$ & $1.273^{*}$ \\
\hline
\end{tabular}

${ }^{1}$ LNNIL, LNOML, LNPSDP, and UC are log of Net Investment, log of manufacturing output, log of Public Sector Development Plan and cost of capital respectively. The usage of ' $d$ ' in front of the variables indicate that the variables are in differenced form. 
Note: The level of significance at $1 \%, 5 \%$ and $10 \%$ is indicated respectively by *, ${ }^{* *}$, and ${ }^{* *}$. The optimal lag order in the case of ADF and the bandwidth for PP test is regulated by the Schwarz Information Criteria.

Source: Author's Estimation

After selection of lag order based on Schwarz criteria, keeping in mind the sensitivity of the F-statistics for cointegration to the lag length, the F-statistic is calculated. The results of the bounds test show that the Fstatistics is 4.86 . This value is higher than the upper bound value of 4.35 (lower bound is 3.23 ) at $5 \%$ level of significance. This infers a rejection of the null hypothesis of no long run relationship existence at the $5 \%$ level of significance. Thus this establishes the presence of cointegration amongst the variables of interest. The presence of the long run relationship is proof of Granger-causality (at least in one direction).

The ARDL model demonstrates the slope-estimated coefficients (long run) and the dynamic-estimated coefficients (short run) (Li \& Lin, 2015). Each variables' optimum lag length is taken in the model. Pesaran and Shin (1998), and Narayan (2004) recommend that for annual observations two lags as the maximum order can be chosen. Therefore, following Duasa (2007) the current study also selected two order of lags and used SC to ascertain the "optimal number of lags to be included in the conditional ECM". The dynamic parameters (short run) are attained by the estimation of the error correction model related with the long run estimates. Using this error correction term OLS regression is run. Usage of SC as a selection criteria to select the orders of the ARDL model gives the result of $(1,0,0,0)$.

\section{Table 4: ARDL Bounds Test}

\begin{tabular}{|l|l|l|}
\hline Optimal lag structure & $(1,0,0,0)$ \\
\hline F-statistics & $4.86^{\star}$ & \\
\hline Critical Value Bounds & \multicolumn{2}{|l|}{} \\
\hline Significance & Lower Bounds, I (0) & Upper Bounds, I (1) \\
\hline 1 percent & 4.29 & 5.61 \\
\hline 2.5 percent & 3.69 & 4.89 \\
\hline 5 percent & 3.23 & 4.35 \\
\hline Note: ${ }^{*}$ significant at 5 percent level & \\
\hline
\end{tabular}

Source: Author's Estimation

\section{Table 5: ARDL Cointegrating and Long run relationship}

\begin{tabular}{|l|l|c|l|l|}
\hline \multicolumn{2}{|l|}{ Dependent variable is Log of Net Investment } \\
\hline Regressors & Coefficient & Standard errors & T-statistics & Probability \\
\hline Output & 1.02 & 0.28 & 3.65 & 0.000 \\
\hline PSDP & 1.22 & 0.52 & 2.32 & 0.026 \\
\hline Cost of Capital & -2.72 & 1.75 & -1.55 & 0.129 \\
\hline
\end{tabular}

Source: Author's Estimation

The above table displays the influence of the regressors on the regressand. Manufacturing output and PSDP are found to be significant at 1 percent and 5 percent respectively in the long-run; however, the cost of capital though having the correct sign is not found to be significant. The long-run elasticities of manufacturing output and PSDP contributing to investment are 1.02 and 1.22 respectively. Thus this shows that both the variables have a positive impact on investment in the long run. This means a 1 percent increase in PSDP raises the investment by 1.22 percent in the long run. The user cost of capital negatively effects the investment, though the results are not considered as significant. There is minimal significance of the dummies except the one which captures the political environment of the economy. Therefore, in the long run only the political environment dummy effects investment level. Besides the dummies, out of the other regressors, manufacturing output is the only variable which is highly significant depicting that investment is very sensitive 
to it in the long run. The next step is to find the short run impact of the variables on the investment. For this the error correction mechanism is used. The residual using the long run coefficients is calculated.

Table 6: Error correction representation of the selected ARDL model

\begin{tabular}{|c|c|c|c|c|}
\hline \multicolumn{5}{|c|}{ Dependent variable is $\Delta$ In (Net Investment) } \\
\hline Regressors & Coefficient & $\begin{array}{l}\text { Standard } \\
\text { errors }\end{array}$ & T-statistics & Probability \\
\hline$\Delta \ln$ (Output) & -0.081 & 0.85 & -0.095 & 0.93 \\
\hline$\Delta \ln (\mathrm{PSDP})$ & 0.662 & 0.307 & 2.15 & 0.039 \\
\hline$\Delta \ln ($ Cost of capital) & -2.358 & 0.642 & -3.669 & 0.0009 \\
\hline ecm $(-1)$ & -0.799 & 0.236 & -3.387 & 0.0019 \\
\hline R-squared & 0.56 & \multicolumn{2}{|c|}{ Durbin-Watson statistics } & 2.278 \\
\hline Adjusted R-squared & 0.44 & & F-statistic & $4.894(0.000)$ \\
\hline
\end{tabular}

Source: Author's Estimation

The Durbin-Watson Statistic is 2.278. Since the value is near 2, there is no statistical indication of autocorrelation of the error terms. The F-statistic, which compares the joint effect of all the variables simultaneously, is found to be highly significant.

In the long-run, the cost of capital was not found to be significant, whereas in the short-run the cost of capital is highly significant. Cost of capital and PSDP are found to be significant at $1 \%$ and $5 \%$ respectively in the short run; however, manufacturing output has the wrong sign and is highly insignificant. The short-run elasticities of cost of capital and PSDP promoting investment are -2.36 and 0.66 respectively. This implies that while cost of capital pulls investment down, the PSDP has a positive influence on investment in the shortrun. Thus in the short-run if there is a ten percent increase in PSDP, it will increase investment by 6.6 percent and a ten percent increase in cost of capital will decrease investment by 23.6 percent.

The error correction term depicts the speed of adjustment of the variable to return to its equilibrium level. The equilibrium error correction term has a coefficient of -0.80 , and it has the expected negative sign. The t ratio is -3.39 and it is highly significant, i.e. 0.00. Accordingly, it can be established that in the short run the adjustment mechanism is very meaningful. This indicates that nonconformity from the long run equilibrium is corrected by $79.9 \%$ over each year. This means that when there is a shock it takes approximately two years to reach back to the equilibrium. The results indicate that causality runs reciprocatively from PSDP and user cost of capital to investment, through the error correction term.

The results of the diagnostic test run on the ECM show that the residuals are normally distributed showing that the model is internally consistent. When the errors are not dependent on the regressands and are independently and identically distributed, they are said to be normal. The test for misspecification has the null hypothesis of normality. Since the p-value is greater than 0.05; therefore, there is a failure to reject the null hypothesis and the residuals are normally distributed. Ramsey Regressions Specification Error Test (RESET) is the test for general misspecifications. The results show that the $p$-value is greater than the 0.05 level of significance and thus there is a failure to reject the null hypothesis of correct specification. It is concluded that the model is not misspecified.

The diagnostics of the short run model also show that there is an absence of autocorrelation and heteroskedasticity. The Breusch-Godfrey LM test is used to detect presence of serial correlation. Since the $\mathrm{p}$-value is greater than the 5 percent significance level, therefore, there is a failure to reject the null hypothesis and thus serial correlation is not a problem. Heteroskedasticity test shows that the P-value is much greater than the level of significance; therefore, there is a failure to reject the null hypothesis of homoscedasticity. Autoregressives conditional heteroskedasticity $(\mathrm{ARCH})$ model is used to check if the variances of the errors are serially uncorrelated. Results show that there are no ARCH effects. The t-statistics is 0.717 . LM statistics is less than the chi square and thus there is a failure to reject the null of no ARCH effects. 
Table 7: Short Run Diagnostic tests

\begin{tabular}{|l|c|c|}
\hline & Statistics & Probability \\
\hline Serial Correlation LM Test & 2.82 & 0.076 \\
\hline ARCH Test & 0.534 & 0.465 \\
\hline Heteroscedacticity Test & 0.384 & 0.921 \\
\hline Jarque-Bera Test & 0.479 & 0.787 \\
\hline Ramsey RESET Test & 0.127 & 0.724 \\
\hline
\end{tabular}

Source: Author's Estimation

To investigate the constancy of the long run coefficients and the short run dynamics, the stability diagnostics i.e. CUSUM (cumulative sum) and the CUSUMsq (cumulative sum of squares) of the recursive residual test for structural stability are done (as suggested by Pesaran and Shin, 1999). The plots, as displayed below, show that they are within the critical bounds, which are represented by the straight lines $(5 \%$ level of significance). There is a failure to reject the null hypothesis, the regression equation is correctly specified and has stable recursive residuals. ${ }^{2}$

Figure 1: Plot of Cumulative Sum of Recursive Residuals (CUSUM)

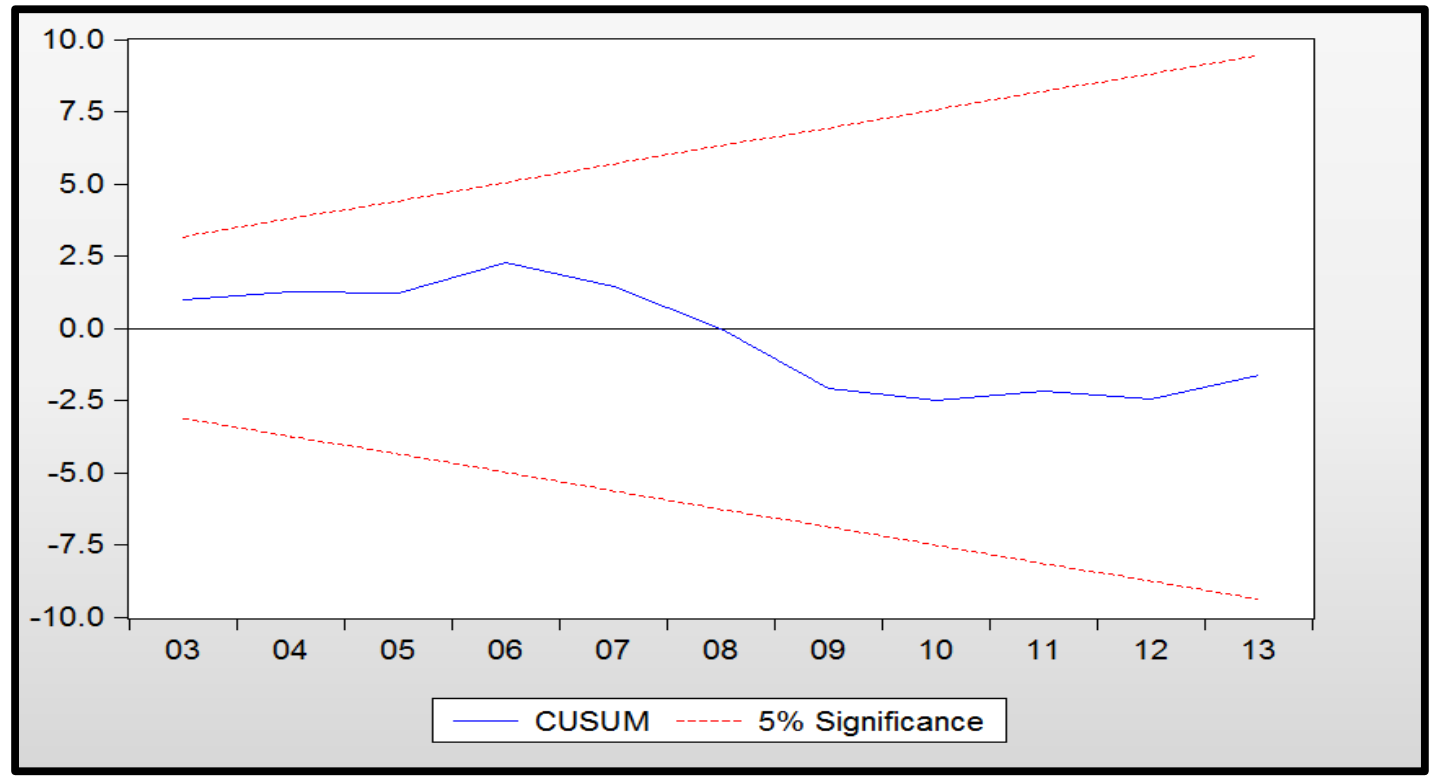

Source: Author's Estimation

Figure 2: Plot of Cumulative Sum of squares of Recursive Residuals (CUSUMsq)

\footnotetext{
${ }^{2}$ It can be observed in the figures that they start from 2003 onwards. In order to test the stability of the model from the beginning of the series, the stability diagnostics were forced to omit all the dummies. Omission of dummies had a small effect on the short run coefficients and their significance level whereas the CUSUM and CUSUMsq figures were obtained from 1980 onwards. The results of this manipulation still kept the plots within the critical bounds thus assuring of model stability.
} 


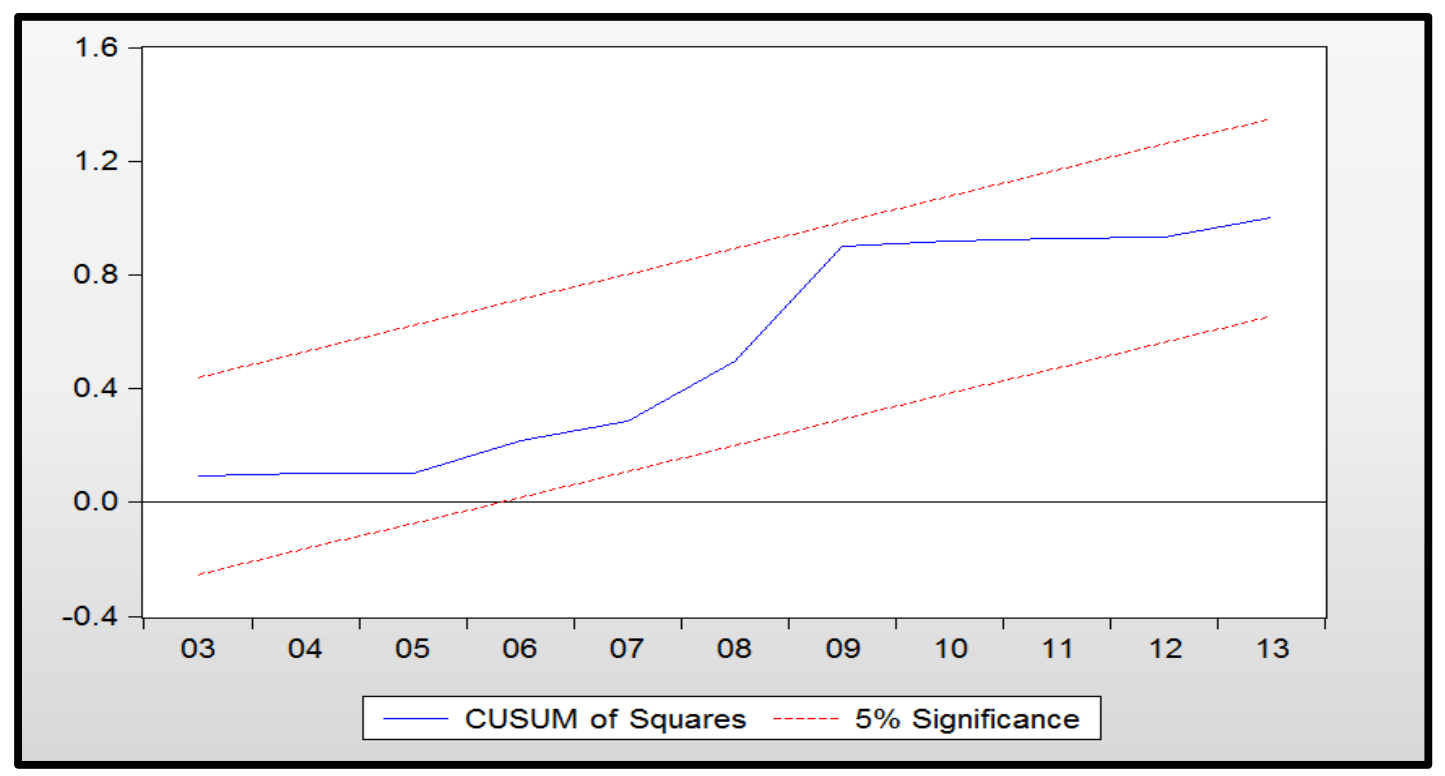

Source: Author's Estimation

\section{Simulation of Investment}

Finally, to see the potency of both the expenditures to enhance investment level, a simulation of investment is conducted. PSDP was found significant in both the short and the long run. PSDP encompasses all governmental investments such as infrastructure. On the other hand the tax expenditure, working through the cost of capital, was found highly significant in the short run. It is assumed in the analysis of testing the relative potency of the two expenditures that the cost associated with either of them is same for the government. Also, it should be kept in mind that this is not a Walrasian general equilibrium analysis but a partial equilibrium analysis. Thus impact on other factors being absent from the current study limits the findings of the current study.

It should also be noted here that tax expenditure is attained by the interaction of the initial depreciation allowance, tax rate, and the predicted level of investment. All these variables effect the value of the tax expenditure. The tax expenditure, that is the accelerated depreciation allowance given to the firms, is removed from the cost of capital. After it is removed the new cost of capital is calculated. The tax expenditure amount which now the government is receiving in the form of tax revenue is added to the PSDP. It is assumed that the government is using the increased tax revenue, due to the reduction of the tax expenditure, completely to finance more of PSDP. This new level of PSDP and the new value of cost of capital is now used in the earlier regression to get the simulated investment series. The new series generated gives a new level of investment referred here as simulated investment. Please see the table below to observe the new series. The table displays the actual level of investment; the predicted investment, attained through the first regression; the tax expenditures amount, which now the government is acquiring; and the simulated investment, attained through the second regression.

Table 8: Simulation Results (in million Rs)

\begin{tabular}{|rrrrr|}
\hline & $\begin{array}{r}\text { Actual } \\
\text { Investment }\end{array}$ & $\begin{array}{r}\text { Predicted } \\
\text { Investment }\end{array}$ & $\begin{array}{r}\text { Tax } \\
\text { Expenditures }\end{array}$ & $\begin{array}{r}\text { Simulated } \\
\text { Investment }\end{array}$ \\
\hline \hline 1972 & 101378 & 13445 & 1849 & 12539 \\
1973 & 26999 & 17961 & 2470 & 18724 \\
1974 & 8171 & 8998 & 1237 & 10569
\end{tabular}




\begin{tabular}{|c|c|c|c|c|}
\hline 1975 & 19447 & 26175 & 3599 & 28451 \\
\hline 1976 & 34839 & 19289 & 2652 & 18178 \\
\hline 1977 & 30182 & 23041 & 3168 & 22199 \\
\hline 1978 & 19626 & 38732 & 5326 & 37086 \\
\hline 1979 & 27855 & 55669 & 7655 & 55689 \\
\hline 1980 & 48695 & 70540 & 9699 & 72459 \\
\hline 1981 & 58754 & 82495 & 11343 & 87046 \\
\hline 1982 & 58830 & 71382 & 9815 & 71056 \\
\hline 1983 & 79196 & 73255 & 10073 & 70901 \\
\hline 1984 & 96083 & 73810 & 10149 & 72971 \\
\hline 1985 & 133909 & 86279 & 11863 & 85203 \\
\hline 1986 & 144727 & 89526 & 12310 & 83740 \\
\hline 1987 & 86700 & 94743 & 13027 & 92825 \\
\hline 1988 & 79699 & 133019 & 18290 & 134286 \\
\hline 1989 & 106090 & 126046 & 14180 & 129092 \\
\hline 1990 & 129558 & 79661 & 8962 & 79255 \\
\hline 1991 & 137199 & 98773 & 12347 & 101245 \\
\hline 1992 & 101052 & 120000 & 15000 & 118491 \\
\hline 1993 & 108803 & 85595 & 11769 & 82636 \\
\hline 1994 & 120977 & 79788 & 10372 & 79773 \\
\hline 1995 & 59245 & 83612 & 10242 & 84241 \\
\hline 1996 & 72542 & 34112 & 3923 & 32977 \\
\hline 1997 & 72019 & 70813 & 8144 & 71942 \\
\hline 1998 & 68404 & 65554 & 7047 & 63135 \\
\hline 1999 & 34942 & 54500 & 5859 & 51856 \\
\hline 2000 & 87082 & 115506 & 10107 & 117582 \\
\hline 2001 & 92294 & 97466 & 10478 & 96595 \\
\hline 2002 & 117352 & 69050 & 5956 & 67655 \\
\hline 2003 & 114112 & 75102 & 6571 & 74081 \\
\hline 2004 & 118462 & 148084 & 12957 & 156789 \\
\hline 2005 & 138769 & 94855 & 8300 & 96287 \\
\hline 2006 & 198635 & 155817 & 13634 & 157561 \\
\hline 2007 & 194490 & 177204 & 15505 & 178037 \\
\hline 2008 & 167662 & 251664 & 22021 & 272033 \\
\hline 2009 & 100798 & 146471 & 12816 & 149285 \\
\hline 2010 & 94123 & 95175 & 8328 & 95272 \\
\hline 2011 & 66556 & 59646 & 5219 & 59527 \\
\hline 2012 & 57843 & 89362 & 7819 & 89133 \\
\hline 2013 & 69699 & 80251 & 7022 & 79091 \\
\hline
\end{tabular}

Source: Author's Estimation

The investment elasticity with respect to the change in the cost of capital, due to the depreciation allowance, depicts the potency of the tax expenditure. Interest rate and the tax rate determine the cost of capital. Thus, there is a direct relation of tax expenditure with the tax rate. On the other hand, the elasticity of investment with respect to the new level of PSDP depicts the potency of the direct expenditure. When the simulated investment is subtracted from the predicted investment, it is found that for some years it is less than the predicted level. This leads us to conclude that tax expenditure serves to boost investment more than the PSDP. With the removal of the tax expenditure, the investment level is not as high as the level predicted with 
the tax expenditure. Thus tax expenditure has more influence to alter the level of investment in the economy in those years. However; for the other years, it is observed that simulated investment is more than the predicted investment. This concludes, that in these years, direct expenditure is more effective in boosting investment.

Upon closer scrutiny, it is observed that in periods of high inflation the simulated investment tends to be more than the predicted level of investment. This leads to the premise that PSDP is more effective in periods of high inflation as compared to the tax expenditure. Similarly, in periods of low inflation, the trend communicates that because simulated investment is less than the predicted level of investment, tax expenditure is more effective to boost investment. Exploring this further, the higher inflation rate affects the depreciation allowance value by making it have a lower present value, because the real interest rate is decreased. Thus, the high inflation rate affects cost of capital via the "tax saving depreciation" and increases the cost of capital. Tax expenditure has been able to impact the investment powerfully in the years when the tax rates are high and the real interest rates have been high too. However, when the tax rate is already minimal, the tax expenditure is less effective because the decrease in the rate is also low. When either the tax rate or the interest rate have decreased, the gap between the simulated and the predicted investment has been found to decrease too.

In the period of the study, when the inflation is low, the tax expenditure has a more profound effect on the cost of capital and the elasticity of the cost of capital is greater. Due its direct impact on the cost of capital, tax expenditure is able to boost investment rapidly. This is in line with the finding through the empirical analysis which showed that tax expenditure was highly efficacious in the short run.

\section{Conclusion}

Pakistan needs to boost its economy by attracting more investment and at the same time reduce its expenditures. This research aims to empirically evaluate the potency of the direct and the tax expenditure and deduce as to which fairs better in boosting the level of the much needed investment in the economy using the novelty of ascertaining not only their long run but also their short run relationships with investment. By means of this research, the government will be able to decide which expenditure is more effective.

The results indicated the presence of a strong role of direct expenditure in influencing both the short-run and the long-run behavior of investment in the economy. On the other hand, the cost of capital demonstrated the most dominating role in the short-run to manipulate the level of investment in Pakistan. It was assumed during this analysis that both the expenditures cost the government the same. On assessing which expenditure is able to boost investment the most, it was found that tax expenditure fares much better than the direct expenditure, when the rate of inflation is low. This is deduced by analyzing the cost of capital which encompasses the tax expenditure. In periods of low inflation, the tax expenditure influences the level of investment strongly and the simulated investment is found to be less than the predicted investment. Recall that the simulated investment is one which does not contain tax expenditure and has the enhanced value of PSDP. Meanwhile, when the inflation is high, direct expenditure is generally more effective in boosting the level of the investment in the economy. In most of the periods, of high inflation, the simulated investment is mostly found to be greater than the predicted level of investment.

The result of the present study concludes that tax expenditure, working through the cost of capital, is a significant determinant of investment. This is in conformity with earlier findings on the importance of tax expenditures to enhance the level of investment by (Ahmed, 2001; Cummins, Hassett, \& Hubbard, 1996; Hall \& Jorgenson, 1967; Musgrave \& Musgrave, 1989) as well as Bernstein and Shah (1995, as cited in Zee et al. (2002). On the pretext that there is transparency by the administration, tax expenditures are considered useful (Zee, Stotsky, \& Ley, 2002). Though, (Clark, 1979; Jorgenson, 1967) deduces that tax expenditures' effect takes place in the long run, the current study finds that it impacts investment in the short run.

The current study's results also conform with the findings of Ahmad and Qayyum (2008) whereby they concluded that direct expenditures should be enhanced in order to boost investment in the economy. Both (Akkina \& Celebi, 2002; Hussain, Muhammad, Akram, \& Lal, 2009) too concluded that public sector infrastructure investment complemented private investment. However, Ahmad and Qayyum (2008) stressed that in order to reap the maximum benefit of increased government spending, the government should try to 
keep the rate of inflation low. This finding is not in conformity with the present study, whereby it was found that direct expenditure turned into a stronger determinant of investment in periods of high inflation.

Therefore, in the light of the findings, the policy implication of this study is that when the government expects low inflation, the tax expenditure is a better option to boost the current dwindling level of investment. Especially in the short run, the government of Pakistan should continue and/or introduce such policies that support and enhance tax expenditures in order to decrease the cost of capital for the investors. However, when the government foresees high rates of inflation, the policy of more direct expenditures should be adopted by the government. Developing countries like Pakistan are always finding ways to boost investment, consequently; the policy makers of Pakistan will find the results helpful while devising the level of tax expenditure and direct expenditure. This will provide assistance in the enhancement of the investment, in the economy, and help Pakistan to achieve better growth.

As a future research scope, extension of this present study can be made. This can be done by incorporating, in the cost of capital calculation, the interest deductibility which is also used as a tool for tax expenditure. In different countries interest is also deductible, that augments the level of investment by the decrease of the cost of capital. Hence future study can be to see how interest deductibility, in Pakistan, will effect private investment. 


\section{References}

Ahmad, I., \& Qayyum, A. (2008). Effect of government spending and macro-economic uncertainty on private investment in services sector: Evidence from Pakistan.

Ahmed, A. M., \& Ather, R. (2014). Study on Tax Expenditures in Pakistan. World Bank Policy Paper Series on Pakistan

Ahmed, Q. M. (2001). A test of relative efficacy of tax expenditures and direct expenditures: A neo-classical approach. Journal of Development Economics, 65(2), 477-489.

Akkina, K. R., \& Celebi, M. A. (2002). The determinants of private fixed investment and the relationship between public and private capital accumulation in Turkey. The Pakistan Development Review, 243254.

Altshuler, R., \& Dietz, R. D. (2008). Tax expenditure estimation and reporting: a critical review: National Bureau of Economic Research.

Amjad, R. (2008). Private Industrial Investment in Pakistan. Cambridge Books.

Auerbach, A. J. (1983). Corporate taxation in the United States. Brookings Papers on Economic Activity, 1983(2), 451-513.

Bischoff, C. W., Bosworth, B., \& Hall, R. (1971). Business investment in the 1970s: a comparison of models. Brookings Papers on Economic Activity, 1971(1), 13-63.

Chirinko, R. S. (1993). Business fixed investment spending: Modeling strategies, empirical results, and policy implications. Journal of Economic Literature, 31(4), 1875-1911.

Clark, P. K. (1979). Investment in the 1970s: Theory, performance, and prediction. Brookings Papers on Economic Activity, 1979(1), 73-124.

Fuest, C., \& Riedel, N. (2009). Tax evasion, tax avoidance and tax expenditures in developing countries: A review of the literature. Report prepared for the UK Department for International Development (DFID).

Galindo, A. J., \& Pombo, C. (2011). Corporate taxation, investment and productivity: A firm level estimation. Journal of Accounting and Taxation, 3(7), 158.

Hall, R. E., \& Jorgenson, D. W. (1967). Tax Policy and Investment behavior. American Economic Review, 57, No. 3 (June); 391-414.

Hall, R. E., \& Jorgenson, D. (1971). Application of the theory of optimum capital accumulation. Tax incentives and capital spending.

Hussain, A., Muhammad, S. D., Akram, K., \& Lal, I. (2009). Effectiveness of government expenditure crowding-in or crowding-out: empirical evidence in case of Pakistan. European Journal of Economics, Finance and Administrative Sciences(16). 
Hyder, K., \& Ahmed, Q. M. (2003). Why private investment in Pakistan has collapsed and how it can be restored.

Johansson, Å., Heady, C., Arnold, J., Brys, B., \& Vartia, L. (2008). Taxation and economic growth. OECD Economic Working Papers 620.

Jorgenson, D. (1967). The theory of investment behavior Determinants of investment behavior (pp. 129175): NBER.

Jorgenson, D. W. (1963). Capital theory and investment behavior. The American Economic Review, 53(2), 247-259.

Jorgenson, D. W. (1971). Econometric studies of investment behavior: a survey. Journal of Economic Literature, 9(4), 1111-1147.

Jorgenson, D. W. (1971). The economic impact of Investment Incentives. In Joint Economic Committee, Long term implications of current tax and spending proposals.

Jorgenson, D. W., \& Siebert, C. D. (1968a). A comparison of alternative theories of corporate investment behavior. The American Economic Review, 58(4), 681-712.

Jorgenson, D. W., \& Siebert, C. D. (1968b). Optimal capital accumulation and corporate investment behavior. The Journal of Political Economy, 1123-1151.

Kahn, D. A. (1979). Accelerated Depreciation: Tax Expenditure or Proper Allowance for Measuring Net Income? Michigan Law Review, 78(1), 1-58.

Kahn, D. A. (2013). Proposed Replacement of the Tax Expenditure Concept and a Different Perspective on Accelerated Depreciation, A. Fla. St. UL Rev., 41, 143.

Kemal, A. R. (2006). Key issues in industrial growth in Pakistan. Lahore Journal of Economics, 11(Special Edition), 49-74.

Li, J., \& Lin, Z. (2015). The impact of sales tax on economic growth in the United States: an ARDL bounds testing approach. Applied Economics Letters, 22(15), 1262-1266.

Musgrave, R. A., \& Musgrave, P. B. (1989). Public finance in theory and practice: McGraw-Hill Book Co.

Pasha, H. A., \& Ghaus-Pasha, A. (2015). The Future Path of Tax Reforms in Pakistan. Pakistan, 171.

Pakistan Economic Survey. Various issues.

Pesaran, M. H., \& Shin, Y. (1998). An autoregressive distributed-lag modelling approach to cointegration analysis. Econometric Society Monographs, 31, 371-413.

Pesaran, M. H., Shin, Y., \& Smith, R. J. (2001). Bounds testing approaches to the analysis of level relationships. Journal of applied econometrics, 16(3), 289-326. 
Shah, Z., Ahmed, Q. M., \& Siddiqui, R. (2003). The Determinants of Foreign Direct Investment in Pakistan: an Empirical Investigation [with Comments]. The Pakistan Development Review, 697-714.

Surrey, S. S. (1970). Tax incentives as a device for implementing government policy: A comparison with direct government expenditures. Harvard Law Review, 705-738.

Thuronyi, V. (1988). Tax Expenditures: A Reassessment. Duke Law Journal, 1988(6), 1155-1206.

Waliullah, Kakar, M. K., Kakar, R., \& Khan, W. (2010). The Determinants of Pakistan's Trade Balance: An ARDL Cointegration Approach. The Lahore Journal of Economics, 15(1), 1.

Zaidi, S. A. (2015). Issues in Pakistan's economy. OUP Catalogue. 